\title{
GAMBARAN MANAJEMEN DIRI MAHASISWA SAAT PANDEMI COVID-19 DITINJAU DARI JENIS KELAMIN
}

\section{Rini Nurahaju}

Program Studi Psikologi Fakultas Psikologi Universitas Hang Tuah, email: rini.nurahaju@hangtuah.ac.id

\begin{abstract}
A Covid 19 pandemic has an impact on teaching and learning in Higher Education. Research conducted during the pandemic situation aims to find out the picture of selfmanagement in students. A total of 80 people were involved in this study. Sampling is done by convenience or accidental sampling. The method used is descriptive quantitative method. Data retrieved using a measuring instrument in the form of Self-Management scale. The methods of processing and analyzing statistical data are descriptive and inferential. This means that findings such as gender data, aspects of self-management and other additional data are analyzed descriptively and differences in self-management of male and female students are analyzed inferentially with the Man Whitney test in order to describe the profile of self-management comprehensively. The results showed that there were no significant differences in self-management in male and female students. The level of self-management in students is in the medium category. This means that they are capable enough to plan, organize, carry out / direct and control all activities in this pandemic situation. The implication of this research is as preliminary data to see the profile of self-management in students.
\end{abstract}

Keywords: self-management, students, co-19 pandemic

\section{ABSTRAK}

Pandemi Covid 19 telah berdampak pada proses belajar mengajar di Perguruan Tinggi. Penelitian yang dilakukan saat situasi pandemi tersebut bertujuan untuk mengetahui gambaran manajemen diri pada mahasiswa. Sebanyak 80 orang terlibat dalam penelitian ini. Pengambilan sampel dilakukan dengan convenience atau accidental sampling. Metode yang digunakan adalah metode kuantitatif deskriptif. Data diambil dengan menggunakan alat ukur berupa skala Manajemen Diri. Cara pengolahan dan analisis data statistik bersifat deskriptif dan inferensial. Artinya temuan seperti data jenis kelamin, aspek manajemen diri dan data tambahan lainnya dianalisa secara deskriptif dan perbedaan manajemen diri mahasiswa laki dan perempuan dianalisis secara 
inferensial dengan uji Man Whitney agar dapat menggambarkan profil manajemen diri secara komprehensif. Hasil penelitian menunjukkan bahwa tidak ada perbedaan manajemen diri secara signifikan pada mahasiswa laki-laki dan perempuan. Tingkat manajemen diri pada mahasiswa berada dalam kategori sedang. Artinya mereka cukup mampu untuk merencanakan, mengorganisasikan, melaksanakan/mengarahkan dan mengendalikan semua aktivitas dalam situasi pandemi ini. Implikasi penelitian ini adalah sebagai data awal untuk melihat gambaran profil manajemen diri pada mahasiswa.

Kata Kunci: manajemen diri, mahasiswa, pandemi Covid-19

\section{PENDAHULUAN}

Pada awal tahun 2020 ini, dunia diguncangkan oleh munculnya virus yang dikenal dengan nama COVID-19 (Corona Virus Disease 2019) yang pertama kali ditemukan di kota Wuhan, China pada akhir Desember 2019. Virus ini menular dengan sangat cepat dan telah menyebar ke hampir semua negara, termasuk Indonesia. Hal ini membawa dampak yang sangat besar di bidang ekonomi, pendidikan, sosial, budaya dan sebagainya.

Sebagai dampak di bidang pendidikan, berbagai negara telah mengambil langkah yang sama yaitu menutup sistem PBM (Proses Belajar Mengajar) biasa/tatap muka (offline) menjadi sistem pembelajaran daring (online). Tentu saja dengan menerapkan pembelajaran online institusi harus mengimplementasikannya dengan langkah-langkah yang tepat. Situasi pandemi ini sampai sekarang tidak bisa diketahui kapan berakhirnya. Alhasil proses belajar mengajar di institusi pendidikan termasuk di perguruan tinggi juga terkena imbas yang berkepanjangan.

Mengapa perguruan tinggi menggunakan sistem pembelajaran online? Hal ini dikarenakan untuk menghentikan penyebaran virus melalui interaksi langsung di antara orang banyak. Akibat peralihan proses pembelajaran yang dulunya melalui tatap muka menjadi online memaksa berbagai pihak untuk dapat mengikuti proses dan alurnya, supaya sistem pembelajaran tetap berjalan dengan baik. Berbagai pihak dalam dunia perguruan tinggi/kampus meliputi mahasiswa, dosen dan tenaga kependidikan. Dampak secara langsung tentu saja pada mahasiswa yang mendapatkan proses kuliah dan dosen sebagai tenaga yang mengajarkan materi kuliah. Mau tidak mau, suka tidak suka kedua belah pihak harus menyesuaikan diri dengan metode PBM yang sesuai dengan situasi di 
tengah pandemi ini karena pembelajaran harus terus berjalan untuk mencapai tujuan pendidikan.

Tujuan pendidikan, yaitu mahasiswa lulus dari perguruan tinggi dan menjadi sarjana bermutu atau sesuai dengan ketentuan Peraturan Pemerintah 1990/30 tentang Pendidikan Tinggi yakni menjadi anggota masyarakat yang memiliki kemampuan akademik dan profesional yang dapat menerapkan, mengembangkan serta menciptakan ilmu pengetahuan, teknologi ataupun kesenian. Untuk itu setiap mahasiswa Indonesia harus mengatur dan mengelola dirinya secara sebaik-baiknya. Segenap langkah dan tindakan mengatur dan mengelola diri itu termasuk pengertian manajemen diri. Dengan manajemen diri, mahasiswa bisa mendorong diri sendiri untuk maju, mengatur semua unsur potensi pribadi, mengendalikan kemauan untuk mencapai hal-hal yang baik, dan mengembangkan berbagai segi dari kehidupan pribadi agar lebih sempurna (Gie, 1995). Kehidupan mahasiswa yang penuh dengan tugas baik akademik maupun non akademik menuntut kemampuan untuk melakukan manajemen diri. Seorang mahasiswa dapat menyelesaikan tugas sesuai dengan yang telah direncanakan dan akhirnya akan dapat mencapai tujuan jika memiliki manajemen diri yang baik dan tepat.

Apakah manajemen diri itu? Manajemen berasal dari kata to manage yang artinya mengatur. Pengaturan merupakan suatu proses untuk mewujudkan tujuan yang diinginkan, meliputi apa yang harus dilakukan, menetapkan cara bagaimana melakukannya, memahami bagaimana harus melakukan dan mengukur efektivitas dari usaha-usaha tersebut. Pengaturan dilakukan melalui proses dan diatur berdasarkan urutan dari fungsi-fungsi manajemen yaitu POAC (Planning, Organizing, Actuating, Controlling). Terdapat pendapat yang menyatakan bahwa manajemen merupakan suatu proses untuk membuat terselesaikannya suatu aktivitas secara efisien dan efektif dengan dan melalui orang lain (Fauzi, 2018). Manajemen diri berhubungan dengan masalah pengontrolan tugas yang meliputi bagaimana cara untuk mencapai tujuan belajar dan bagaimana mengatur hasil dan dukungan dari belajar (Garisson dalam Fattah, 2010). Menurut Carol C. Kanar dalam Ayuningtyas (2015), manajemen diri adalah kualitas personal dari disiplin diri atau kontrol diri. Orang-orang yang memanajemen diri dengan baik adalah orang-orang yang dapat memotivasi diri sendiri. Sedangkan menurut Linda Wong dalam Ayuningtyas (2015), manajemen diri adalah kemampuan untuk menggunakan strategi agar mampu berhadapan 
secara konstruktif dan efektif dengan variabel-variabel yang mempengaruhi kualitas dari kehidupan personal. Kemampuan ini mencakup manajemen waktu, motivasi, penyusunan tujuan, manajemen stres, konsentrasi, dan manajemen prokrastinasi. Konsep tersebut bisa disandingkan dan saling melengkapi dengan fungsi-fungsi manajemen POAC.

Planning (perencanaan) merupakan susunan langkah-langkah secara sistematik dan teratur untuk mencapai tujuan tertentu. Menurut Hamalik (2010), perencanaan merupakan rangkaian tindakan ke depan. Perencanaan bertujuan untuk mencapai seperangkat operasi yang konsisten dan terkoordinasi guna memperoleh hasil-hasil yang diinginkan. Dalam konteks ini mahasiswa merencanakan dan menetapkan rencana tindakan yang dilakukan bagaimana memersiapkan diri dalam belajar. Misalnya kapan kuliah, kapan mengerjakan tugas, kapan ujian yang semuanya tentu perlu perencanaan yang berbeda dengan saat kondisi normal.

Organizing (pengorganisasian) berasal dari kata organize, yang berarti menciptakan struktur dengan bagian-bagian yang diintegrasikan sedemikian rupa sehingga hubungan satu sama lain terikat oleh hubungan terhadap keseluruhan. Pengorganisasian adalah fungsi manajemen dan merupakan suatu proses yang dinamis (Fauzi, 2018). Terry (1986) mengemukakan bahwa pengorganisasian adalah tindakan mengusahakan hubungan-hubungan kelakuan yang efektif antara orang-orang, sehingga mereka dapat bekerja sama secara efisien, dan memperoleh kepuasan pribadi dalam melaksanakan tugas-tugas tertentu dalam kondisi lingkungan tertentu guna mencapai tujuan atau sasaran tertentu. Dalam konteks ini, setelah menetapkan rencana, seorang mahasiswa dapat mengorganisasikan atau menyusun strategi belajar yang tepat yang akan digunakan, apakah perlu belajar sendiri, atau dengan berkelompok, apakah dengan membaca, memberi tanda bagian yang penting ataukah dengan mencatat, meringkas dan berbagai strategi yang lain yang mungkin tidak sama pelaksanaannya antara mata kuliah yang satu dengan mata kuliah yang lainnya.

Actuating (pelaksanaan, penggerakan) berarti melaksanakan aktivitas, mengarahkan orang agar mau bekerja sama dan bekerja efektif dalam mencapai sebuah tujuan. Dalam perencanaan dan pengorganisasian lebih banyak berhubungan dengan aspek-aspek abstrak proses manajemen, sedangkan fungsi actuating justru lebih menekankan pada kegiatan yang berhubungan langsung dengan orang-orang. Hal-hal yang telah diorganisasikan dilaksanakan dengan 
penuh keyakinan dan semaksimal mungkin agar apa yang telah direncanakan dan diorganisasikan dapat berjalan dengan baik sesuai dengan harapan. Dalam konteks ini mahasiswa melaksanakan aktivitas perkuliahan, mengerjakan tugas sesuai dengan perencanaan dan pengorganisasian sebelumnya. Perlu kekompakan semua anggota jika tugas yang diberikan menuntut adanya kelompok. Oleh karena itu ketrampilan memimpin, mengarahkan diperlukan oleh mahasiswa.

Controlling (pengawasan / pengendalian) merupakan tahap pelaksanaan apakah sudah sesuai dengan rencana. Pengawasan dapat diartikan sebagai proses untuk menetapkan pekerjaan apa yang yang sudah dilaksanakan, menilainya dan mengoreksi bila perlu dengan maksud supaya pelaksanaan pekerjaan sesuai dengan rencana semula (Manullang,1998). Dalam konteks ini kontrol berbentuk kesadaran diri terhadap pelaksanaan kegiatan belajar yang telah dilakukannya. Apakah dirinya bisa memahami dan menguasai materi tersebut seperti saat diajarkan secara tatap muka? Apakah perlu merubah strategi belajar, bertanya pada dosen tentang materi, untuk minta penjelasan kembali, mengubah lokasi belajar, dan sebagainya. Pada tahap ini mahasiswa mengevaluasi semua yang telah dikerjakan.

Semua fungsi manajemen ini saling terkait, dan tidak lepas satu sama lainnya. Jika semua fungsi berjalan dengan baik maka diharapkan akan baik pula hasilnya. Dalam konteks penelitian ini, sejalan dengan yang diungkapkan oleh Dembo (dalam Ayuningtyas, 2015) bahwa manajemen diri adalah sebuah kunci untuk menjelaskan seorang pelajar atau mahasiswa itu sukses. Manajemen diri adalah suatu faktor yang mempengaruhi proses belajar. Hal tersebut dapat membangun kondisi yang optimal untuk belajar dan membuang pengaruh yang buruk dalam belajar tak terkecuali pada laki-laki dan perempuan.

Pendapat Baron \& Byrne mengatakan bahwa gender secara tidak langsung berpengaruh terhadap pembentukan sikap dan motivasi belajar (Hoang, 2008). Dalam jurnalnya Hoang (2008) mengungkapkan bahwa laki-laki dengan semua karakteristik bawaannya berbeda dengan perempuan. Perbedaanperbedaan tersebut diduga berpengaruh dalam setiap aspek kehidupan yang dialami. Gender merupakan dimensi sosiobudaya dan psikologis dari keberadaan sebagai laki dan perempuan (Santrock, 2007). Peran gender meruapakan seperangkat ekspektansi yang menentukan bagaimana laki dan perempuan sebaiknya berpikir, bertindak dan merasa (Santrock, 2007). William dan Best 
(dalam Santrock, 2007) mengatakan bahwa stereotip terhadap perempuan dan laki sudah cukup menyebar, diberbagai budaya. Laki-laki pada umumnya dianggap sebagai sosok yang dominan, agresif, mandiri, gigih dan berorientasi pada prestasi. Sedangkan perempuan secara luas dianggap sebagai sosok yang mengasuh, kurang percaya diri, gemar berkumpul, dan lebih banyak menolong orang lain yang berada dalam kesulitan. Asumsi tentang faktor gender atau jenis kelamin ini ingin dicermati penulis karena diduga adanya perbedaan antara mahasiswa laki-laki dan perempuan. Untuk itu hipotesis penelitian yang diajukan adalah ada perbedaan manajemen diri mahasiswa ditinjau dari jenis kelamin.

\section{METODE PENELITIAN}

Penelitian ini dilakukan terhadap 80 mahasiswa di perguruan tinggi swasta Surabaya. Peneliti menggunakan teknik pengambilan sampel dengan metode convenience atau accidental sampling, yakni responden dipilih karena ketersediaannya dan adanya keinginan secara sukarela untuk berpartisipasi dalam penelitian (Nazir, 2005). Data diperoleh melalui kuesioner online dengan menggunakan Google form.

Pada penelitian ini penulis menggunakan alat ukur manajemen diri yang terdiri dari 4 buah aspek yakni Planning, Organizing, Actuating dan Controling. Masing-masing aspek berisikan 3 item pernyataan sehingga total berjumlah 12 item. Alat ukur manajemen diri menggunakan skala Likert 1-5, angka 1 menunjukkan respon sangat setuju terhadap pernyataan kuesioner dan angka 5 menggambarkan respon sangat tidak setuju.

Untuk melakukan uji analisis perbedaan manajemen diri yang ditinjau dari jenis kelamin, penulis menggunakan statistik non parametrik yaitu Uji Mann Whitney karena didasarkan alasan (1) uji perbedaan dan (2) variabel jenis kelamin termasuk data nominal (Nisfiannoor, 2009).

\section{HASIL DAN PEMBAHASAN}

Jumlah responden penelitian sebanyak 80 mahasiswa, meliputi 19 lakilaki dan 61 perempuan. Deskriptif variabel penelitian yaitu manajemen diri dilakukan dengan cara membuat kategori pada variabel tersebut. Variabel tersebut dikelompokkan dalam tiga kategori, yaitu Tinggi, Sedang, Rendah 
dengan didasarkan pada norma $27 \%$ batas bawah dan $73 \%$ batas atas (Nisfiannoor, 2009). Hasilnya seperti tertera pada tabel 1:

Tabel 1 : Kategori Tingkat Manajemen Diri

\begin{tabular}{lll}
\hline Kategori & Frekuensi & Prosentase \\
\hline Tinggi & 19 & $23,8 \%$ \\
Sedang & 42 & $52,5 \%$ \\
Rendah & 19 & $23,8 \%$ \\
\hline Total & 80 & $100 \%$ \\
\hline
\end{tabular}

Berdasarkan tabel 1, menunjukkan bahwa dari 80 responden dalam penelitian ini, mayoritas para mahasiswa memiliki tingkat manajemen diri yang termasuk dalam kategori sedang, lalu diikuti dengan tingkat manajemen diri yang sama banyak pada kategori rendah dan kategori tinggi.

Selanjutnya dilakukan uji hipotesis menggunakan Uji Mann-Whitney dengan hasil seperti yang tertera di tabel 2

Tabel 2 : Hasil uji hipotesis

\begin{tabular}{ll}
\hline & Total \\
\hline Mann-Whitney U & 525,000 \\
Wilcoxon W & 2416,000 \\
Z & $-0,617$ \\
Asymp. Sig. (2-tailed) & 0,537 \\
\hline
\end{tabular}

Angka pada tabel 2 menunjukkan tidak adanya perbedaan manajemen diri yang signifikan antara mahasiswa laki dan perempuan, ditunjukkan dengan nilai signifikansi $\mathrm{p}=0,537$. Hal ini mengacu bahwa jika sig (p) > 0,05 maka tidak signifikan (Nisfiannoor, 2009). Dari hasil ini menunjukkan hipotesis dalam penelitian ini ditolak.

Dari item-item yang ditanyakan pada responden terkait aspek manajemen diri maka hasil penelitian seperti tertera pada tabel 3. 
Tabel 3 : Jawaban Responden

\begin{tabular}{|c|c|c|c|c|c|c|}
\hline ASPEK & INTI DARI ITEM & $\begin{array}{l}\text { SS } \\
\text { (Sangat } \\
\text { Setuju) }\end{array}$ & $\underset{\text { (Setuju) }}{\mathrm{S}}$ & $\begin{array}{c}\mathbf{N} \\
\text { (Netral) }\end{array}$ & $\begin{array}{c}\text { TS } \\
\text { (Tidak } \\
\text { Setuju) }\end{array}$ & \begin{tabular}{|c|} 
STS \\
(Sangat \\
Tidak \\
Setuju) \\
\end{tabular} \\
\hline \multirow[t]{3}{*}{ Planning } & $\begin{array}{l}\text { Mengetahui target yang } \\
\text { harus dicapai oleh tiap } \\
\text { kegiatan yang diikuti }\end{array}$ & 25 & 30 & 10 & 10 & 5 \\
\hline & $\begin{array}{l}\text { Menghitung di awal } \\
\text { secara global kebutuhan } \\
\text { tenaga, alat, tempat dan } \\
\text { anggaran }\end{array}$ & 14 & 32 & 21 & 11 & 2 \\
\hline & $\begin{array}{l}\text { Menyusun rencana } \\
\text { kegiatan yang harus } \\
\text { dikerjakan }\end{array}$ & 15 & 25 & 25 & 14 & 1 \\
\hline \multirow[t]{3}{*}{ Organizing } & $\begin{array}{l}\text { Menyusun jadwal } \\
\text { kegiatan secara detil }\end{array}$ & 12 & 29 & 19 & 12 & 8 \\
\hline & $\begin{array}{l}\text { Memilah mana kegiatan } \\
\text { yang harus dikerjakan } \\
\text { terlebih dahulu }\end{array}$ & 24 & 38 & 7 & 4 & 7 \\
\hline & $\begin{array}{l}\text { Mampu mendelegasikan } \\
\text { wewenang jika itu } \\
\text { kegiatan kelompok }\end{array}$ & 5 & 34 & 29 & 9 & 2 \\
\hline \multirow[t]{3}{*}{ Actuating } & $\begin{array}{l}\text { Melakukan terlebih } \\
\text { dahulu kegiatan yang } \\
\text { penting dan mendesak }\end{array}$ & 31 & 33 & 3 & 3 & 10 \\
\hline & $\begin{array}{l}\text { Tidak pernah tergoda } \\
\text { untuk melakukan } \\
\text { kegiatan sampingan jika } \\
\text { kegiatan yang wajib } \\
\text { belum selesai }\end{array}$ & 7 & 23 & 29 & 14 & 7 \\
\hline & $\begin{array}{l}\text { Memberi motivasi pada } \\
\text { kelompok untuk } \\
\text { mengerjakan tugas } \\
\text { dengan senang hati }\end{array}$ & 14 & 31 & 25 & 9 & 1 \\
\hline \multirow[t]{2}{*}{ Controlling } & $\begin{array}{l}\text { Mengontrol } \\
\text { permasalahan atau } \\
\text { kendala yang ditemui } \\
\text { dalam setiap kegiatan }\end{array}$ & 13 & 36 & 22 & 6 & 3 \\
\hline & $\begin{array}{l}\text { Merekap semua hasil } \\
\text { kegiatan akademik } \\
\text { maupun non akademik } \\
\text { setiap waktu }\end{array}$ & 4 & 18 & 39 & 17 & 2 \\
\hline
\end{tabular}


Rini Nurahaju : Gambaran Manajemen Diri Mahasiswa Saat Pandemi Covid-19 Ditinjau dari Jenis Kelamin

\begin{tabular}{|c|l|c|c|c|c|c|}
\hline ASPEK & \multicolumn{1}{|c|}{ INTI DARI ITEM } & $\begin{array}{c}\text { SS } \\
\text { (Sangat } \\
\text { Setuju) }\end{array}$ & $\begin{array}{c}\text { S } \\
\text { (Setuju) }\end{array}$ & $\begin{array}{c}\text { N } \\
\text { (Netral) }\end{array}$ & $\begin{array}{c}\text { TS } \\
\text { (Tidak } \\
\text { Setuju) }\end{array}$ & $\begin{array}{c}\text { STS } \\
\text { (Sangat } \\
\text { Tidak } \\
\text { Setuju) }\end{array}$ \\
\hline & $\begin{array}{l}\text { Membandingkan semua } \\
\text { kegiatan yang telah } \\
\text { dicapai dengan tahun- } \\
\text { tahun sebelumnya }\end{array}$ & 24 & 31 & 10 & 10 & 5 \\
\hline
\end{tabular}

Hasil penelitian ini menunjukkan bahwa tidak ada perbedaan manajemen diri jika dikaitkan dengan jenis kelamin. Artinya baik laki-laki atau perempuan mempunyai tingkat manajemen diri yang sama. Hal ini hampir sama dengan penelitian yang dilakukan Damayanti dkk (2012). Pada responden yang sama yakni mahasiswa tidak ada perbedaan gaya belajar yang signifikan ditinjau dari tipe kepribadian dan jenis kelamin. Begitu juga dengan penelitian yang dilakukan oleh Anita (2015) yang menunjukkan bahwa tidak ditemukan perbedaan signifikan pada motivasi belajar mahasiswa laki-laki dan perempuan. Penelitian terkait manajemen diri antara mahasiswa laki-laki dan perempuan pernah dilakukan oleh Syamsu dan Milla (2014). Hasil studi terhadap 605 mahasiswa menunjukkan mereka tidak berbeda dalam manajemen diri yang meliputi aspek manajemen diri, mengambil keputusan dan menjalankan agama.

Jika dikaitkan dengan aspek manajemen maka tampak bahwa tingkat manajemen diri mahasiswa laki dan perempuan tergolong sedang. Artinya mereka cukup mampu untuk merencanakan, mengorganisasikan, melaksanakan/ mengarahkan dan mengendalikan semua aktivitas dalam situasi pandemi ini. Perencanaan merupakan proses terpenting dari semua fungsi manajemen. Suatu manajemen tidak mungkin berjalan jika tidak ada perencanaan. Hal ini rupanya disadari betul oleh responden, terbukti dengan mayoritas responden yakni 30 mahasiswa mengetahui target yang harus dicapai pada setiap kegiatan yang diikuti. Dengan adanya tujuan yang jelas dan terarah maka mereka mengetahui dengan baik tujuan yang hendak dicapai. Artinya mereka memahami prosedur apa saja yang akan dilakukan sebagaimana ada dalam perencanaan. Dengan adanya perencanaan akan memberikan pandangan mengenai tindakan apa saja yang harus dilakukan demi tercapainya tujuan, termasuk di dalamnya biaya dan lamanya waktu yang dibutuhkan sehingga tujuan tereralisasi. Hal ini sesuai dengan jawaban responden (32 mahasiswa ) yang menyatakan bahwa mereka 
menghitung di awal secara global kebutuhan tenaga, alat, tempat dan anggaran untuk rencana kegiatannya. Keuntungan perencanaan ini akan membantu responden mengurangi resiko dan ketidakpastian yang akan menghadang pencapaian tujuan sehingga dapat diminimalisasi. Namun dalam hal penyusunan rencana ternyata tidak sepenuhnya responden selalu menyusunnya. Jumlah responden yang menjawab setuju dan menjawab netral, masing-masing sama (25 mahasiswa). Artinya dalam penelitian ini responden sama banyak antara mereka yang mempunyai kebiasaan menyusun rencana dan yang tidak. Jika dikaitkan dengan situasi pandemi ini, proses belajar online diakui oleh mahasiswa membutuhkan biaya yang tidak sedikit terutama untuk pembelian pulsa / paket data untuk bisa mengakses perkuliahan. Hal yang lain terkait teknis seperti pengaturan waktu kuliah yang terkadang terjadi ketidaksamaan dengan saat kuliah tatap muka. Hal ini menimbulkan penyusunan kembali jadwal belajar yang efektif disesuaikan dengan situasi tersebut. Lebih detil lagi mahasiswa menentukan lokasi belajar yang nyaman, tidak bising supaya tidak terganggu dengan situasi sekitar, karena umumnya mahasiswa belajar di rumah atau kost yang lingkungannya tentu tidak sama dengan kampus. Kesemuanya ini memerlukan perencanaan yang matang untuk bisa mengantisipasi semua situasi kondisi tersebut.

Setelah merencanakan umumnya akan dikuti oleh mengorganisasikan. Pada dasarnya pengorganisasian merupakan upaya untuk melengkapi rencanarencana yang telah dibuat dengan susunan organisasi pelaksananya. Hal yang penting untuk diperhatikan dalam pengorganisasian adalah bahwa setiap kegiatan harus jelas siapa yang mengerjakan, kapan dikerjakan, dan apa targetnya. Dari hasil penelitian ini tampak bahwa mayoritas responden (29 mahasiswa) menyusun jadwal dengan lebih detil. Mereka bisa memilah mana kegiatan yang harus dikerjakan terlebih dahulu (38 orang). Dua aspek utama proses susunan struktur organisasi yaitu departementalisasi dan pembagian kerja. Departementalisasi adalah pengelompokan kegiatan-kegiatan kerja organisasi. Pembagian kerja adalah perincian tugas pekerjaan agar setiap individu bertanggungjawab dalam melaksanakan sekumpulan kegiatan. Jika hal ini dikaitkan dengan proses belajar mengajar, maka membutuhkan ketelitian mahasiswa, misalnya terdapat dosen dalam mengajar dan mengumpulkan tugas menggunakan zoom, google classroom, whatsapp, line, email dan sebagainya. Begitu juga dengan waktu pengumpulan tugas-tugas dari dosen tersebut, perlu 
strategi yang detil, misalnya mana tugas yang perlu deadline segera dan mana yang dikumpulkan kemudian hari dan sebagainya. Tugas tersebut ada yang harus dikerjakan secara individu ada juga yang harus berkelompok. Dalam hal tugas kelompok baik dalam tugas akademik atau tugas ekstra kurikuler, mayoritas (34 mahasiswa) telah mampu mendelegasikan wewenang pada anggota kelompok.

Pada tataran pelaksanaan, umumnya permasalahan terjadi disebabkan karena ketidakmampuan mahasiswa mengelola waktu yang bersumber pada bisa tidaknya mereka memahami manakah prioritas dan mana yang tidak, mana yang penting dan mana yang tidak. Mahasiswa seringkali melakukan hal-hal yang penting menurut dirinya namun hal tersebut bukanlah hal yang merupakan tujuan belajarnya dikampus. Hal-hal yang didahulukan seringkali bukanlah prioritasprioritas yang berhubungan dengan akademik. Hal tersebut terjadi pada responden penelitian ini. Hasil penelitian menunjukkan bahwa mereka terkadang tergoda untuk melakukan kegiatan sampingan walaupun kegiatan yang wajib belum selesai (29 orang). Mereka seharusnya hanya membuka situs yang dibutuhkan dalam menunjang kegiatan belajar, bukan malah membuka situs yang tidak ada kaitannya dengan kuliah. Walaupun demikian dari penelitian ini diketahui mayoritas mahasiswa (33 orang) melakukan terlebih dahulu kegiatan yang penting dan mendesak. Mereka mengikuti proses belajar-mengajar, memperhatikan uraian yang disampaikan dosen, membaca materi dan aktif dalam diskusi dan memecahkan masalah yang diberikan. Dalam hal kegiatan yang dikerjakan secara kelompok mereka cukup mampu memberi motivasi pada kelompoknya untuk mengerjakan tugas dengan senang hati.

Fungsi manajemen yang terakhir adalah controlling atau pengendalian. Tujuan utama dari pengawasan ialah mengusahakan agar apa yang direncanakan menjadi kenyataan. Untuk dapat merealisasikan tujuan utama, maka pengawasan pada taraf pertama bertujuan agar pelaksanaan pekerjaan sesuai dengan instruksi yang telah dikeluarkan dan untuk mengetahui kelemahan-kelamahan serta kesulitan-kesulitan yang dihadapi. Mayoritas mahasiswa dapat mengontrol permasalahan atau kendala yang ditemui (36 orang). Kendala ini bisa meliputi infrastruktur internet, penguasaan fasilitas teknologi (zoom, google classroom, whatsapp, line, email dll), tugas-tugas yang bertumpuk dan waktu pengumpulannya yang berdekatan dan sebagainya. Tentu ini tidak mudah bagi yang tidak terbiasa mengelola diri. Mereka perlu menghindari hal-hal yang mempengaruhi konsentrasi saat belajar misalnya dengan cara mematikan televisi, 
mematikan nada dering smartphone dan menjauhkan letaknya dari jangkauan supaya tetap fokus. Tidak semua mahasiswa mempunyai kebiasaan merekap semua hasil kegiatan akademik maupun non akademik setiap waktu. Lebih banyak (39 mahasiswa) yang menjawab netral. Artinya mereka tidak menentukan sikap setuju atau tidak setuju. Untuk evaluasi, mayoritas mereka (31 mahasiswa) membandingkan semua kegiatan yang telah dicapai dengan tahun-tahun sebelumnya. Kebiasaan ini cukup baik karena berdasarkan penemuan-penemuan tersebut dapat diambil tindakan untuk memperbaiki baik pada waktu situasi pandemi ini ataupun waktu-waktu yang akan datang.

\section{PENUTUP}

\section{Simpulan}

Hasil penelitian ini sudah sesuai dengan tujuan penelitian yakni berupaya mengetahui gambaran manajemen diri pada mahasiswa baik laki maupun perempuan. Temuan menunjukkan bahwa tidak ada perbedaan manajemen diri yang signifikan antara mahasiswa laki-laki dan perempuan. Mereka sama-sama mempunyai tingkat manajemen diri yang cukup baik. Dengan kata lain mayoritas mereka cukup mampu untuk merencanakan, mengorganisasikan, melaksanakan/mengarahkan dan mengendalikan semua aktivitas walaupun dalam situasi pandemi ini. Implikasi penelitian ini sebagai data awal untuk melihat gambaran manajemen diri pada mahasiswa.

\section{Saran}

Penelitian ini selanjutnya diharapkan dapat menggugah peneliti lain untuk menggali lebih lanjut dengan metode lain misalnya wawancara mendalam atau melibatkan faktor-faktor terkait lainnya untuk dapat menjelaskan manajemen diri lebih detil dan menyeluruh. Keterampilan manajemen diri sangat diperlukan bagi mahasiswa sehingga semakin banyak kajian pada topik ini akan memberikan wawasan yang semakin luas sehingga diharapkan dapat membantu pihak-pihak yang berkepentingan. 


\section{DAFTAR PUSTAKA}

Anita, I.W. 2015. Pengaruh Motivasi Belajar Ditinjau Dari Jenis Kelamin

Terhadap Kemampuan Berpikir Kritis Matematis Mahasiswa. Jurnal Ilmiah UPT P2M STKIP Siliwangi, 2 (2).

Ayuningtyas, I. 2015. Tingkat Pengaturan Diri Dalam Bidang Akademik Pada Mahasiswa Bimbingan Dan Konseling Di Universitas Negeri Yogyakarta.

Skripsi. Fakultas Ilmu Pendidikan Universitas Negeri Yogyakarta.

Damayanti, A.K., Pratitis, N.T. 2012 Gaya Belajar Ditinjau Dari Tipe Kepribadian Dan Jenis Kelamin. Jurnal Persona Psikologi Indonesia .1 (2).

Fattah. 2010. Garrison's Model Of Self-Directed Learning: Preliminary Validation And Relationship To Academic Achievement. The Spanish Journal Of Psychology. 13(2).

Fauzi., Irviani, R. 2018. Pengantar Manajemen. Edisi Revisi Yogyakarta: Andi.

Gie. L. 1995. Cara Belajar Yang Efisien Jilid II Edisi Keempat (Diperbaharui). Yogyakarta: Liberty.

Hamalik, O. 2010. Perencanaan Pengajaran Berdasarkan Pendekatan Sistem. Jakarta

Hoang, T. N. 2008. The Effect Of Grade Level, Gender, And Ethnicity On Attitute And Learning Environment In Accounting In High School: International Electronic Journal Of Accountuing Education. Vol. 3.

Manullang, M. 2000. Manajemen Sumber Daya Manusia. Yogyakarta: Andi.

Nazir, M. 2005. Metode penelitian. Bogor: Ghalia Indonesia.

Nisfiannoor, M. 2009. Pendekatan Statistika Modern untuk Ilmu Sosial, Jakarta: Salemba Humanika.

Peraturan Pemerintah 1990/30 Tentang Pendidikan Tinggi.

Santrock, J.W. 2007. Remaja Edisi Sebelas, Erlangga.

Siswanto, B. 2010. Manajemen Tenaga Kerja Rancangan Dalam Pendayagunaan Dan Pengembangan Unsur Tenaga Kerja. Bandung : Sinar Baru.

Syamsu, M.N., Milla, M.N. 2014. Pengalaman Kegagalan pada Laki-laki dan Perempuan, Jurnal Psikologi. 10 (2).

Terry, G.R. 2006. Prinsip- Prinsip Manajemen. Jakarta: Bumi Aksara. 